\title{
Dwarf Yaupon Holly Response to Fertilizer Application Rate and Frequency
}

\author{
Thomas H. Yeager
}

Additional index words. nutrition, container plants, Ilex

\begin{abstract}
Summary. Ilex vomitoria Ait. 'Nana' root and-shoot growth increased as rate of fertilizer applied from a $6 \mathrm{~N}-$ 1P-3K solution increased from 0.5 to $2.5 \mathrm{~g} \mathrm{~N} / 3$-liter container during a 26-week experiment. Percentage of applied N, P, and Kin the plant and growth medium decreased as $\mathbf{N}$ applied increased. Dividing the fertilizer among one, two, or four applications per week resulted in similar use of applied $\mathbf{N}, P$, and $K$. Shoot dry weights for the $0.5 \mathrm{~g} \mathrm{~N} /$ container treatment were less than for the Osmocote $(18 \mathrm{~N}-2.6 \mathrm{P}-10 \mathrm{~K})$ treatment ( $2.5 \mathrm{~g}$ N/container), but the percentage of applied $N, P$, and $K$ in the plant and growth medium $(55 \%, 42 \%$, and $75 \%$, respectively) was greater than for the Osmocote treatment $(31 \%, 15 \%$, and $27 \%$, respectively).
\end{abstract}

$\mathrm{C}$ ontainer nursery operators are implementing more-efficient fertilization practices because of increased environmental awareness. Efficient fertilization should result in maximum use of applied fertilizer without compromising plant growth. For agronomic crops, fertilizer use depends on appli-

Department of Environmental Horticulture, IFAS, University of Florida, Gainesville, FL 32611.

Florida Agricultural Experiment Stations journal series no. R-04693. I gratefully acknowledge Misty Farm Nurs-

ery, Brooker, Fla., for supplying plant material and Holland's Tree Nursery, Jacksonville, Fla., for their cooperation. I gratefully acknowledge Claudia Larsen, Environmental Horticulture, and Terry Del Valle, Duval County Cooperative Extension Service, for their excellent assistance. Trade names and companies are mentioned with the understanding that no endorsement is intended nor discrimination implied for similar products not mentioned. The cost of publishing this paper was defraved in part by the payment of page charges. Under postal regulations, this paper therefore must be hereby marked advertisement solely to indicate this fact. 
cation rate (Millard and Robinson, 1990; Stevens and Laughlin, 1989) and frequency or timing (Baligar and Bennett, 1986). Baligar and Bennett (1986) estimated that, for tropical and subtropical conditions, use of applied $\mathrm{N}$ and $\mathrm{P}$ was $<50 \%$ and $10 \%$, respectively, while use of applied $\mathrm{K}$ was about $40 \%$. Stevens and Laughlin (1989) determined that $\mathrm{N}$ use was $76 \%$ for ryegrass when averaged over several sites, $\mathrm{N}$ fertilizer carriers, and application rates. Yeager et al. (1980) determined that container-grown Ilex crenata Thunb. 'Helleri' used $19 \%$ of applied $\mathrm{N}$ and $\mathrm{P}$, and $18 \%$ of applied $\mathrm{K}$ when fertilized weekly with $20 \mathrm{~N}-8.7 \mathrm{P}-$ 16.7 $\mathrm{K}$ in irrigation water. The purpose of this research was to determine the influence of three fertilizer rates and the frequency of application on growth and percentage of applied $\mathrm{N}, \mathrm{P}$, and $\mathrm{K}$ used by Ilex vomitoria Ait. 'Nana.'

\section{Materials and methods}

Three fertilizer rates applied once a week in a nursery (Expt. 1). Multiple branched liners of I. vomitoria 'Nana' were potted 8 Apr. 1987 with a 4 pine bark : 1 Florida peat : 1 builders' sand (by volume) medium in 3-liter containers. The medium was amended with dolomitic limestone, Fritted Trace Elements (F-5030X, FRH Industries, Ozark, Ala.), and superphosphate $(19 \% \mathrm{P})$ at $8.3,1.2$, and $1.5 \mathrm{~kg} \cdot \mathrm{m}^{-3}$, respectively. The plants were placed in a, randomized complete-block design on black polypropylene groundcover in a production nursery at Jacksonville, Fla., and irrigated as needed with $0.5 \mathrm{~cm}$ of water applied twice daily by overhead irrigation. One plant in each of 15 blocks received either $2.5 \mathrm{~g}$ of $\mathrm{N}$ surfaceapplied in one application as Osmocote (18N-2.6P-10K, 8 to 9 month longevity at 21C, O.M. Scott and Sons Co., Marysville, Ohio) or a total of $0.5,1.5$, or $2.5 \mathrm{~g}$ of $\mathrm{N}$ per container from a solution that contained a ratio of $6 \mathrm{~N}-1 \mathrm{P}-3 \mathrm{~K}$. Nitrogen, $\mathrm{P}$, and $\mathrm{K}$ fertilizer carriers were $\mathrm{NH}_{4} \mathrm{~N} \mathrm{O}_{3}$, $\mathrm{KH}_{2} \mathrm{PO}_{4}$, and $\mathrm{K}_{2} \mathrm{SO}_{4}$, respectively. The solution fertilizer was applied once a week during the 26-week experiment. The total $\mathrm{N}$ applied per container was divided equally into 26 applications and dissolved in $50 \mathrm{ml}$ of deionized water. Plants fertilized with Osmocote received $50 \mathrm{ml}$ of deionized water when other plants received a fertilizer solution. Twenty-six weeks after ex- periment initiation, growth medium was removed from roots and roots were dipped in deionized water to remove fine growth medium particles. Stems were severed above the uppermost roots and root and shoot dry weights were determined after drying at $70 \mathrm{C}$ in a forced air oven.

Three fertilizer rates applied once a week in a glass greenhouse (Expt. 2). Multiple branched liners of I. vomitoria 'Nana' were potted 3 June 1987 with a 2 pine bark : 1 Canadian peat : 1 builders' sand (by volume) medium in 3-liter containers. Growth medium was amended with dolomitic limestone and Perk (Vigoro Industries, Winter Haven, Fla.) at 3 and 1.8 $\mathrm{kg} \cdot \mathrm{m}^{-3}$, respectively. The plants were placed on a bench in a randomized complete-block design in a glass greenhouse (21C minimum). A single plant was used for each treatment in 12 blocks. Solution and Osmocote fertilizer rates and number of applications were as in Expt. 1. Each plant received $460 \mathrm{ml}$ of deionized water 1 and 4 days (Thursday and Monday, respectively) before the solution fertilizer treatments were applied (Friday). Twenty-six weeks after experiment initiation, root and shoot dry weights were determined as in Expt. 1.
Three fertilizer rates applied one, two, or four times a week in a glass greenhouse (Expt. 3). This experiment began on 20 May 1988 and was similar to Expt. 2, except that each rate of solution fertilizer was applied using three application frequencies. Three-liter containers were filled with $1175 \mathrm{~g}$ of media that contained a particle size distribution (by weight) of $71.5 \%<0.5 \mathrm{~mm}, 13.4 \%$ between 0.5 and $1.4 \mathrm{~mm}, 8.1 \%$ between 4.0 and $1.4 \mathrm{~mm}, 2.7 \%$ between 6.4 and 4.0 $\mathrm{mm}$, and $4.3 \%>6.4 \mathrm{~mm}$ (U.S. series sieve nos. 35, 14, 5, and 3, respectively). Growth medium particle size distribution was determined by shaking five replicate 500-g samples for 20 min with a portable sieve shaker (W.S. Tyler, Mentor, Ohio). Growth media from 12 extra containers and dried roots and shoots of $12 \mathrm{I}$. vomitoria 'Nana' liners were retained for N, P, and $\mathrm{K}$ analyses.

Experimental plants were placed on a greenhouse bench in a randomized complete-block design of three fertilizer rates and three application frequencies. A single plant was used in each of 12 blocks for each factorial combination of solution fertilizer rate and application frequency. One plant in each block received a total of either

Table 1. Root and shoot dry weight of nursery-grown Ilex vomitoria 'Nana' that received a total of $0.5,1.5$, or $2.5 \mathrm{~g}$ of $\mathrm{N} / 3$-liter container from 26 weekly fertilizer applications of a solution that contained $6 N-1 P-3 K$ or one application of Osmocote $18 N-2.6 P-10 K$ (Expt. 1).

\begin{tabular}{llcr}
\hline \multirow{N}{*}{$\begin{array}{l}\text { rate } \\
(\mathrm{g} / \text { container })\end{array}$} & Fertilizer & \multicolumn{2}{c}{ Dry wt $(\mathrm{g})$} \\
\cline { 3 - 4 } 0.5 & Solution & $3.5^{*}$ & Shoots \\
1.5 & Solution & 4.3 & $9.2^{*}$ \\
2.5 & Solution & 5.4 & $13.3^{*}$ \\
& & $\mathrm{~L}^{*}$ & 16.5 \\
2.5 & Osmocote & 5.1 & $\mathrm{~L}^{*}$ \\
& & & 17.7
\end{tabular}

"Significant (Dunnett's) at $\mathrm{P}=0.05 ; L=$ linear.

Table 2. Root and shoot dry weight of greenhouse-grown Ilex vomitoria 'Nana' that received a total of $0.5,1.5$, or $2.5 \mathrm{~g}$ of N/3-liter container from 26 weekly fertilizer applications of a solution that contained $6 N-1 P-3 \mathrm{~K}$ or one application of Osmocote $18 N-2.6 P-10 \mathrm{~K}$ (Expt. 2).

\begin{tabular}{lccc}
\hline \multirow{2}{*}{$\begin{array}{l}\text { N rate } \\
(\mathrm{g} / \text { container })\end{array}$} & Fertilizer & \multicolumn{2}{c}{ Dry wt $(\mathrm{g})$} \\
\cline { 3 - 4 } 0.5 & Solution & 8.5 & Shoots \\
1.5 & Solution & 11.4 & $17^{*}$ \\
2.5 & Solution & 9.0 & 25 \\
& & $\mathrm{~L}^{\mathrm{Ns}}$ & 23 \\
& & $\mathrm{Q}^{*}$ & $\mathrm{~L}^{*}$ \\
2.5 & Osmocote & 10.4 & $\mathrm{Q}^{*}$ \\
& & & 24
\end{tabular}

$\overline{N S,{ }^{*} \text { Nonsignificant or significant at } \mathrm{P}=0.05 . L=\text { linear, } Q=\text { quadratic. The change in slope at each data }}$ point was significant $(\mathrm{P}=0.05)$ for all quadratic responses except roots that received $1.5 \mathrm{~g} \mathrm{~N}$. 
$0.5,1.5$, or $2.5 \mathrm{~g} \mathrm{~N}$ from a solution that was applied one, two, or four times per week (one time = Friday, two times = Friday and Tuesday, or four times = Friday, Saturday, Tuesday, and Wednesday) for a total of 26,52 , or 104 applications during the 26-week experiment. Total $\mathrm{N}$ applied per container $(0.5,1.5$, or $2.5 \mathrm{~g})$ was divided equally into each application and dissolved in $50 \mathrm{ml}$ of deionized water. Each plant received $460 \mathrm{ml}$ of deionized water 1 and 4 days (Thursday and Monday, respectively) before plants in the solution fertilizer treatment groups received the $50 \mathrm{ml}$ fertilizer application on Friday. An additional plant in each block was surface-fertilized once at experiment initiation with Osmocote [18N-2.6P-10K (2.5 g N)] and received $460 \mathrm{ml}$ of deionized water on Monday and Thursday, and $50 \mathrm{ml}$ of deionized water on Friday. Container leachates were collected for all plants at weeks 1, 9, 17, and 25 on Friday immediately before the $50-\mathrm{ml}$ application of solution fertilizer or deionized water was applied. Leachates were collected using the Virginia Tech extraction procedure (Yeager et al., 1983), and leachate $\mathrm{NO}_{3}-\mathrm{N}$ concentrations were determined by cadmium reduction (U.S. Environmental Protection Agency, 1983) at the Univ. of Florida Analytical Research Laboratory.

Twenty-six weeks after experiment initiation, root and shoot dry weights were determined as in Expt. 1. Root and shoot tissue and the growth medium from six replicate plants for each treatment were ground by a Cyclone Mill (UDY Corp., Fort Collins, Colo.). Root and shoot N, P, and K percentages were determined by The O.M. Scotts Co. Testing Laboratory, Fogelsville, $\mathrm{Pa}$, and growth medium total $\mathrm{N}\left(\mathrm{NO}_{3}-\mathrm{N}\right.$ plus Kjeldahl $\left.\mathrm{N}\right), \mathrm{P}$ and $\mathrm{K}$ were determined according to procedures of the Univ. of Georgia Extension Soil Testing and Plant Analysis Laboratory (Isaac and Johnson, 1984). Nitrogen, $P$, and $K$ percentages were multiplied by root, shoot, and growth medium dry weights, respectively, to determine final elemental content of roots, shoots, and growth medium. Initial average $\mathrm{N}, \mathrm{P}$, and $\mathrm{K}$ was determined for roots, shoots, and growth medium of the 12 plants retained at beginning of experiment. Initial elemental content was subtracted from final elemental content to determine $\mathrm{N}, \mathrm{P}$, and $\mathrm{K}$ that accumulated in plants and growth medium. Final growth medium $\mathrm{P}$ content for all treatments was less than initial $\mathrm{P}$ content due to the large quantity of indigenous $\mathrm{P}$ in pine bark, which leaches rapidly (Yeager and Wright, 1982). Therefore, growth medium $\mathrm{P}$ content was not included in calculation of percentage of $\mathrm{P}$ used by the plant system (roots + shoots + growth medium). A similar situation existed for $\mathrm{K}$ in all treatments except for the high $\mathrm{K}$ application rate applied one or four times per week. Only growth medium N content for $0.5 \mathrm{~g} \mathrm{~N}$ applied four times per week was excluded from calculating percentage of $\mathrm{N}$ used by the plant system (roots + shoots + growth medium). In another experiment (unpublished, 1994), I determined that a pine bark, Canadian peat, and sand growth medium contained indigenous water soluble $\mathrm{N}$ and $\mathrm{K}$.

Total plant plus growth medium $\mathrm{N}, \mathrm{P}$, and $\mathrm{K}$ that accumulated was divided by the amount of $\mathrm{N}, \mathrm{P}$, and $\mathrm{K}$ applied, respectively, to determine percent used by the container plant system (roots + shoots + growth medium). Data were evaluated by regression analyses and comparisons made to the Osmocote treatment using Dunnett's procedure (Steel and Torrie, 1960). SAS's (Cary, N.C.) inverse matrix procedure was used to evaluate the change in slope at each data point when response was quadratic.

\section{Results and discussion}

Root and shoot dry weights in Expts. 1, 2, and 3 increased as $\mathrm{N}$ applied increased from 0.5 to 1.5 or 0.5 to $2.5 \mathrm{~g} /$ container (Tables 1-3). There was no interaction in Expt. 3 between $\mathrm{N}$ applied and number of fertilizer applications for root and shoot dry weights and percentage of applied $\mathrm{N}, \mathrm{P}$, and $\mathrm{K}$ used by the plant and media. Root and shoot dry weights and percentage of applied $\mathrm{N}, \mathrm{P}$, and $\mathrm{K}$ used were not different due to the number of fertilizer applications (Table 3). This indicates that weekly fertilizer applications result insufficient $\mathrm{NO}_{3}-\mathrm{N}$ levels in the media compared to two or four applications per week. Hicklenton and Cairns (1992 ) fertilized Cotoneaster dammeri C.K. Schneid 'Coral Beauty' with either Type 100 Nutricote 16N-4.4P-8.1K (Chisso-Asahi Fertilizer Co., Tokyo) or Type 40/100 that would release a portion of the $\mathrm{N}$ more rapidly than type 100 and found that, after 4 months, plant dry weights were not different due to fertilizer type, and dry weights increased as application rate increased to $10 \mathrm{~kg} \cdot \mathrm{m}^{-3}$. This is similar to my results in that higher application rates resulted in more shoot dry weight for Ilex, while shoot dry weights were not different due to number of fertilizer applications made each week. Hicklenton and Cairns (1992) concluded that growth response of cotoneaster was influenced more by the total quantity of nutrients available during the season than by availability at specific times.

Root and shoot dry weights for plants that received 1.5 or $2.5 \mathrm{~g} \mathrm{~N}$ applied as a solution in Expts. 2 and 3 were not different from plants that received $2.5 \mathrm{~g} \mathrm{~N}$ from Osmocote (Tables 2 and 3). Applying $1.5 \mathrm{~g}$ of $\mathrm{N}$ in place of $2.5 \mathrm{~g} \mathrm{~N}$ during a 26-week period would result in a $40 \% \mathrm{~N}$ savings. However, in Expt. 1, applying $1.5 \mathrm{~g}$ of $\mathrm{N}$ resulted in smaller shoot dry weights than plants that received $2.5 \mathrm{~g}$ $\mathrm{N}$ from Osmocote. This might have

Table 3. Root and shoot dry weights and percent of applied $N, P$, and $K$ in roots, shoots, and media from greenhouse-grown Ilex vomitoria 'Nana' that received a total of 0.5, 1.5, or $2.5 \mathrm{~g}$ of N/3-liter container applied as either 26, 52, or 104 applications or one application of Osmocote $18 N-2.6 P-10 K$ (Expt. 3).

\begin{tabular}{|c|c|c|c|c|c|c|}
\hline \multirow{2}{*}{$\begin{array}{l}N \text { rate } \\
\text { (g/container) }\end{array}$} & \multirow[b]{2}{*}{ Fertilizer } & \multicolumn{2}{|c|}{ Dry wt (g) } & \multicolumn{3}{|c|}{$\begin{array}{c}\% \text { of Applied } \\
\text { (roots + shoots + media) }\end{array}$} \\
\hline & & Roots & Shoots & $\mathbf{N}$ & $\mathbf{P}$ & $\mathbf{K}$ \\
\hline 0.5 & Solution & 6.6 & $17^{*}$ & $55^{*}$ & $42^{*}$ & $75^{*}$ \\
\hline 1.5 & Solution & 7.3 & 22 & 36 & 23 & $39^{*}$ \\
\hline \multirow[t]{3}{*}{2.5} & Solution & 7.8 & 24 & 33 & 20 & 35 \\
\hline & & $\mathrm{L}^{*}$ & $\mathrm{~L}^{*}$ & $\mathrm{~L}^{*}$ & $\mathrm{~L}^{*}$ & $\mathrm{~L}^{*}$ \\
\hline & & $\bar{Q}^{\mathrm{NS}}$ & $Q^{*}$ & $Q^{N S}$ & $Q^{*}$ & $Q^{*}$ \\
\hline 2.5 & Osmocote & 7.3 & 24 & 31 & 15 & 27 \\
\hline
\end{tabular}

Ns, ${ }^{*}$ Nonsignificant or significant at $\mathrm{P}=0.05 . L=$ linear, $Q=$ quadratic. Rate $\times$ number of applications interaction wasnonsignificant for dry weights and percentage of applied $N, P$, and $K$. The change in slope at each data point was significant $(\mathrm{P}=0.05)$ for all quadratic responses. 


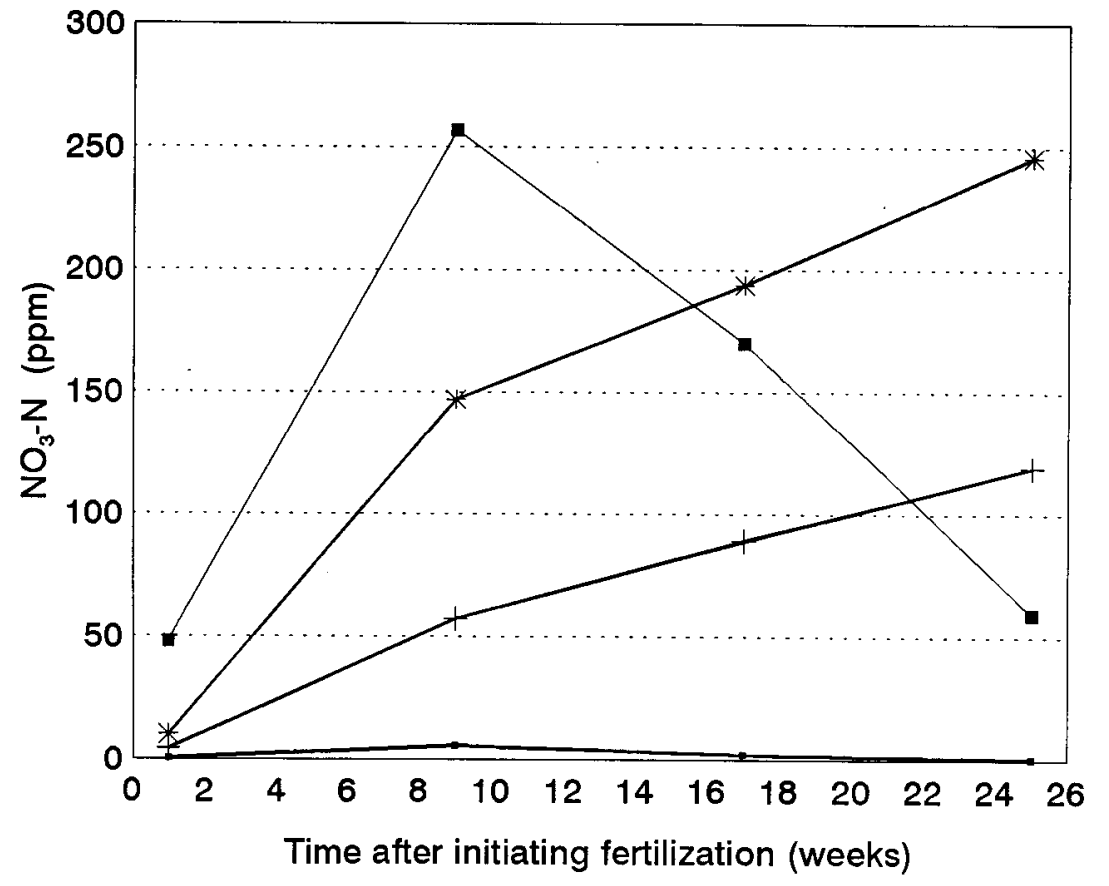

Fig. 1. Leachate $\mathrm{NO}_{3}-\mathrm{N}$ levels for greenbousegrown Ilex vomitoria 'Nana' grown for 26 weeks in 3-liter containers and fertilized with a total of $0.5(\mathrm{D}), 1.5(+)$, or $2.5 g\left(^{*}\right)$ of $N$ per 3-liter container applied as a solution $(6 N-1 P-3 K)$, or for plants fertilized with one application $(2.5 \mathrm{~g} \mathrm{~N}$ ) of Osmocote (匚) $18 \mathrm{~N}-$ $2.6 P-10 K$. Total $N$ per container from the solution fertilizer was aperaged over one, two, or four applications per week.

resulted because time of irrigation applications was not sequenced with time of fertilizer applications in Expt. 1. Consequently, $\mathrm{NO}_{3}-\mathrm{N}$ could have leached soon after applied. In Expts. 2 and 3, irrigation immediately preceded fertilization. The total amount of $\mathrm{N}$ in media at the end of Expt. 3 was compared using Dunnett's test and found to be similar for treatments that received 1.5 or $2.5 \mathrm{~g} \mathrm{~N}$ as a solution, or $2.5 \mathrm{~g} \mathrm{~N}$ from Osmocote (data not shown ).

Percentage of applied N, P, and K used by the plant system decreased as solution fertilizer application rate increased (Table 3). This indicates that more fertilizer would be used if nurseries maintained low but adequate nutritional levels in container medium. Broschat (1995) used a production system similar to that reported here and found that $49 \%, 28 \%$, and $39 \%$ of $\mathrm{N}, \mathrm{P}$, and $\mathrm{K}$, respectively, was leached in 6 months when a solution fertilizer was applied weekly. My data indicate elemental losses between $25 \%$ to $80 \%$. However, Broschat (1995) did not report the nutrient uptake for Spathiphyllum Schott. 'Mauna Loa Supreme.' Spathiphyllum plants grown in his study had slightly greater shoot mass than the Ilex in my investigation and would be expected to have much greater root masses. Consequently, nutrient uptake would be greater for the Spathyllum, resulting in use of more fertilizer than would be expected with a slow-growing woody plant. Stewart et al. (1981) determined that for the woody plant Ligustrum japonicum Thunb. grown in a 2 pine : 1 sand (v/v) growth medium, 33\% of applied $\mathrm{N}$ was used by the plant and growth medium after 84 days.

Controlled-release fertilizers, such as Osmocote, are designed to release small quantities of nutrients over an extended period of time to maintain relatively low nutritional levels in the container medium. Previous work by Yeager and Ingram (1989) revealed that container leachate $\mathrm{NO}_{3}-\mathrm{N}$ levels from Osmocote $18 \mathrm{~N}-2.6 \mathrm{P}-10 \mathrm{~K} \quad(2.5$ g N/3-liter container) were about 48 ppm 1 week after surface application and decreased steadily when plants were watered daily or as needed. However, in the present study, $\mathrm{NO}_{3}-\mathrm{N}$ levels for Osmocote were highest at week 9, then decreased (Fig. 1). The use of Osmocote resulted in fluctuating $\mathrm{NO}_{3}-\mathrm{N}$ levels compared to solution fertilization and did not result in a greater use of applied $\mathrm{N}, \mathrm{P}$, or $\mathrm{K}$ by the plant system. Perhaps if $\mathrm{NO}_{3}-\mathrm{N}$ release from Osmocote had been more uniform or if $\mathrm{NO}_{3}-\mathrm{N}$ would have been available at a time of high uptake, a greater percentage of applied $\mathrm{N}$ would have been used.

In conclusion, these data indicate that percentage of applied $\mathrm{N}, \mathrm{P}$, or $\mathrm{K}$ used by I. vomitoria 'Nana' and the growth medium was higher after 26 weeks when a solution fertilizer supplied $0.5 \mathrm{~g}$ N/3-liter container compared to $2.5 \mathrm{~g} \mathrm{~N}$ from the solution or $2.5 \mathrm{~g} \mathrm{~N}$ supplied from controlledrelease Osmocote $18 \mathrm{~N}-2.6 \mathrm{P}-10 \mathrm{~K}$. However, shoot dry weights were largest when plants were grow-n with 2.5 than $0.5 \mathrm{~g} \mathrm{~N}$. Applying $1.5 \mathrm{~g}$ of $\mathrm{N}$ applied as a solution resulted in comparable shoot dry weight to $2.5 \mathrm{~g} \mathrm{~N}$ applied as Osmocote when equivalent quantities of irrigation water were applied. Dividing the total amount of fertilizer applied into one, two, or four applications per week resulted in similar shoot dry weights and percentages of $\mathrm{N}, \mathrm{P}$, and $\mathrm{K}$ used by the plant and growth medium. Thus, there was no advantage to plant growth or fertilizer use with more than one application per week. Consequently, plant producers will need to achieve a balance between the lowest fertilizer application rate that results in maximum nutrient use and the highest rate that results in acceptable growth. This was achieved for container-grown I. vomitoria 'Nana' in this study by applying $1.5 \mathrm{~g}$ of $\mathrm{N}$ from a $6 \mathrm{~N}-1 \mathrm{P}-3 \mathrm{~K}$ solution divided into 26 weekly applications.

\section{Literature Cited}

Baligar, V.C. and O.L. Bennett. 1986. NPKfertilizer efficiency-A situation analysis for the tropics. Fert. Res. 10:147-164.

Broschat, T.K. 1995. Nitrate, phosphate, and potassium leaching from containergrown plants fertilized by several methods. HortScience 30:74-77.

Hicklenton, P.R. and K. G. Cairns. 1992. Solubility and application rate of controlledrelease fertilizer affect growth and nutrient uptake in containerized woody landscape plants. J. Amer. Soc. Hort. Sci. 117:578583.

Isaac, R.A. and W.C. Johnson. 1984. Methodology for analysis of soil, plant, feed, water and fertilizer samples. Soil Testing and Plant Analysis Laboratory, Univ. of Georgia, Athens.

Millard, P. and D. Robinson. 1990. Effect of the timing and rate of nitrogen fertilization on the growth and recovery of fertil- 
izer nitrogen within the potato (Solanum tuberosum L.) crop. Fert. Res. 21:133140.

Steel, R.G.D. and J.H. Torrie. 1960. Principles and procedures of statistics. McGraw Hill, New York.

Stevens, R.J. and R.J. Laughlin. 1989. A microplot study of the fate of ${ }^{15} \mathrm{~N}$-labelled ammonium nitrate and urea applied at two rates to ryegrass in spring. Fert. Res. 20:3339.

Stewart, J.A., L.J. Lund, and R.L. Branson. 1981. Nitrogen balances for containergrown privet. J. Amer. Soc. Hort. Sci. 106:565-569.

U.S. Environmental Protection Agency. 1983. Methods for chemical analysis of water and wastes. U.S. EPA Monitoring and Support Laboratory, Cincinnati, Ohio. EPA-600/4-79-020.

Yeager, T.H. and D.L. Ingram. 1989. Response of Ligustrum and azalea to surface and growth medium-incorporated fertilizer applications. Proc. Fla. State Hort. Soc. 102:269-271.

Yeager, T.H. and R.D. Wright. 1982. Pine bark-Phosphorus relationships. Comm. Soil Sci. Plant Anal. 13:57-66.

Yeager, T.H., R.D. Wright, and M.M. Alley. 1980. Response of Ilex crenata Thunb. cv. Helleri to timed fertilizer applications. J. Amer. Soc. Hort. Sci. 105:213-215.

Yeager, T.H., R.D. Wright, and S.J. Donohue. 1983. Comparison of pourthrough and saturated pine bark extract $\mathrm{N}$, $\mathrm{P}, \mathrm{K}$, and $\mathrm{pH}$ levels. J. Amer. Soc. Hort. Sci. 108:112-114. 